Article

\title{
Press Freedom and Corruption Perceptions: Is There a Reputational Premium?
}

\author{
Michael Breen ${ }^{1, *}$ and Robert Gillanders ${ }^{2,3}$ \\ ${ }^{1}$ School of Law and Government, Dublin City University, Dublin 9, Ireland; E-Mail: michael.breen@dcu.ie \\ 2 Business School, Dublin City University, Dublin 9, Ireland; E-Mail: robert.gillanders@dcu.ie \\ ${ }^{3}$ Department of Economics, Hanken School of Economics, 00100 Helsinki, Finland \\ * Corresponding author
}

Submitted: 9 December 2019 | Accepted: 7 February 2020 | Published: 28 May 2020

\begin{abstract}
Many studies find a strong association between press freedom and corruption perceptions (Adsera, Boix, \& Payne, 2003; Brunetti \& Weder, 2003; Freille, Haque, \& Kneller, 2007). However, it is possible that this relationship is driven by experts' belief that limits on press freedom are associated with corruption. This article tests the association between press freedom and corruption perceptions using objective measures of corruption from the World Bank's Enterprise Surveys, a series of representative surveys of the owners and top managers of private firms in the manufacturing and service sectors. Our findings suggest that there is a reputational premium associated with press freedom: Holding corruption experiences constant, corruption perceptions are improved by greater press freedom. Moreover, we find that the developed world is best placed to avail of this premium, as it is most evident in countries with low to moderate levels of corruption by global standards.
\end{abstract}

\section{Keywords}

corruption; corruption perception; press freedom; media freedom; premiums

\section{Issue}

This article is part of the issue "Fighting Corruption in the Developed World: Dimensions, Patterns, Remedies" edited by Fabrizio Di Mascio (University of Turin, Italy) and Simona Piattoni (University of Trento, Italy).

(C) 2020 by the authors; licensee Cogitatio (Lisbon, Portugal). This article is licensed under a Creative Commons Attribution 4.0 International License (CC BY).

\section{Introduction}

Many studies find that a free press improves perceptions of corruption, with most arguing that journalists have clear incentives to uncover and report corruption (Adsera, Boix, \& Payne, 2003; Brunetti \& Weder, 2003; Freille, Haque, \& Kneller, 2007). These studies acknowledge two particular mechanisms. The first, taking inspiration from Becker's (1968) model of crime, is that a free press should lower actual corruption levels by increasing the expected costs of corruption for would-be criminals. With would-be criminals facing higher costs, we should observe and perceive less corruption in society, and popular corruption indicators-to the extent that they are accurate-should reflect this reality. The second mechanism is that corruption experts may use press freedom as a mental shortcut, or heuristic device, when compiling corruption perceptions indices. If experts do this rou- tinely, then press freedom may improve corruption perceptions irrespective of actual corruption levels.

While the literature acknowledges that both mechanisms are plausible, no study has tested empirically the proposition that the second mechanism is a meaningful driver of corruption perceptions. This is substantively important because if the second mechanism is driving outcomes, then some countries may enjoy a reputational premium, such that experts give them better assessments than one might expect given the levels of experienced corruption. To test this conjecture, we examine the hypothesis that an improvement in press freedom is associated with an improvement in corruption perceptions, while holding experienced corruption constant. In order to measure experienced corruption, we use the World Bank's Enterprise Surveys, a series of representative surveys of the owners and top managers of private firms in the manufacturing and service sectors. 
Our findings suggest that there is a reputational premium: Holding corruption experiences constant, corruption perceptions are improved by greater press freedom.

Having found evidence for a reputational premium on average, we then ask if it is available to all countries. Our results show that low to moderately corrupt countries can see gains from improving press freedom. This finding has important implications. First, it suggests that in very corrupt countries a free press will not change corruption perceptions unless it changes the reality of corruption. Second, it suggests that developed countries would see reputational gains from improved press freedom, as they tend to enjoy low to moderate levels of corruption compared to other groups.

While press freedom is often considered the hallmark of a developed country, data from Reporters Without Borders show that it is under threat in many OECD countries. In Greece, for example, journalists are frequently arrested under legislation-the 'flagrant procedure'-dealing with press crimes. In Poland, actions to nationalize the media since 2015 have made it increasingly difficult for journalists to dissent from the government's position without being subject to harassment and prosecution. Even in Ireland, which is a relatively clean country by global standards, media ownership is highly concentrated and journalists are constrained by strict libel laws. Furthermore, while many developed countries such as these may have necessary anticorruption laws and policies, their effectiveness may depend critically on press freedom. Mungiu-Pippidi and Dadašov (2017), for example, show some of the most important tools do not always work in isolation and require public scrutiny, underlining the importance of press freedom.

The loss of reputation has real world consequences. Many studies demonstrate that higher corruption perceptions can harm national wellbeing by repelling foreign direct investment (Wei, 2000) and undermining important outcomes such as GDP growth (Mauro, 1995) and interpersonal and institutional trust (Anderson \& Tverdova, 2003; Banerjee, Duflo, Glennerster, \& Kinnan, 2015; Chang \& Chu, 2006; Seligson, 2002). This latter effect on trust in the state and its agents can undermine support for democracy, even in the developed world. To limit reputational damage, policymakers should focus considerable efforts and resources on protecting media freedoms and implementing needed reforms.

In the next section, we discuss the literature on corruption and press freedom. Section 3 presents our data and method. Section 4 presents and discusses our results. In Section 5 we conclude with a discussion of the substantive importance and policy-relevance of our findings.

\section{Press Freedom and Corruption: Literature and Argument}

There is a scholarly consensus that a free press has an important role in the fight against corruption. Many empirical studies demonstrate a strong link between vari- ous indicators of corruption perceptions and press freedom. Brunetti and Weder's (2003) seminal study finds a strong correlation in a sample of 125 countries from 1994 to 1998, Adsera et al. (2003) detect a similar pattern in two samples across multiple time periods, as do Freille et al. (2007) using alternative estimation techniques. Moreover, scholars have considered in detail the role of moderating factors such as the level of democracy level (Chowdhury, 2004; Kalenborn \& Lessmann, 2013), and the level sociopolitical integration (Charron, 2009). In virtually all tests, the association between press freedom and corruption holds, and is robust to a range of controls and estimation techniques.

However, there are unanswered questions about the substantive effect of press freedom on corruption (Färdigh, Andersson, \& Oscarsson, 2011). As we have seen, the majority of existing studies support two particular mechanisms - the first where press freedom makes criminal behavior costlier, reducing corrupt activity and thus perceptions of corruption, and the second where it simply changes experts' perceptions of corruption, irrespective of actual corruption levels. A large literature in corruption studies has questioned the accuracy of experts' perceptions, and other perception-based measures, arguing that they suffer from perception biases (Fan, Lin, \& Treisman, 2009; Reinikka \& Svensson, 2006; Svensson, 2003; Treisman, 2007). Taking our motivation from this literature, we argue that the experts who compile national-level corruption indicators may associate state control of the media with higher levels of corruption, irrespective of actual corruption levels, resulting in a reputational premium.

Whether this premium exists depends on the extent to which experts do this routinely. Yet, there are several reasons why corruption experts may systematically equate media freedoms with corruption. First, experts may conflate a lack of press freedom with a lack of transparency and accountability in society. Corruption is more likely in such environments and as a consequence, expert assessments may be stricter regardless of experienced corruption. By contrast, where there is greater transparency, experts may have more confidence in their own ability, or the ability of their sources, to detect corruption. Second, experts require information to make judgements about corruption. Countries that lack press freedom have limited the flow of information in society, potentially raising uncertainty among experts about the accuracy of their assessments. This may trigger cognitive biases such as conservatism or negativity, leading to less favorable assessments. Third, press freedom may simply be a mental shortcut or heuristic device for compiling corruption perceptions indices. Experts are aware of the evidence linking press freedom to corruption and may use this knowledge to rank countries, regardless of changes in corruption experiences. While these possibilities are not an exhaustive description of reasons why there may be a reputational premium, they suggest that such a premium is plausible. Moreover, the factors that we have 
outlined, such as mental shortcuts and uncertainty have been proven to play an important role in expert decisionmaking in other domains such as investment decisions (Mosley, 2003).

While a reputational premium is plausible, it does not rule out a direct role for press freedom in the fight against corruption. In fact, there is growing support for a link between press freedom and alternative corruption outcomes. Flavin and Montgomery (2019), for example, find that the gap between citizens' perceptions and experts' assessments of corruption narrows considerably at higher levels of press freedom, suggesting that press freedom is essential in bringing corruption to light. Binhadab, Breen, and Gillanders (2018) show that greater press freedom is associated with a lower incidence of corruption as reported by firms in World Bank's Enterprise Surveys, establishing a link between press freedom and a reduction in corrupt activity. Finally, Mungiu-Pippidi and Dadašov (2017) show that key anticorruption tools require public scrutiny to be effective, further underlining the importance of press freedom. In summary, our argument regarding the possibility of a reputational premium linked to press freedom is plausible given what we know about the nature of international corruption indicators, and at the same time it is compatible with the existing evidence that there is a substantial direct link between press freedom and real corruption, and indeed anti-corruption outcomes.

The next logical question is whether the reputational premium hypothesis can be tested, given the challenges inherent in measuring corruption and the limitations of corruption indicators such as the Transparency International's Corruption Perceptions Index and the World Bank's Worldwide Governance Indicators. To address these concerns, researchers have developed new strategies and techniques for measuring corruption.

First, field and lab experiments have become increasingly popular, examining phenomena such as the link between bribery and gender (Armantier \& Boly, 2011) and the degree of reciprocity between bribers and public officials (Abbink, Irlenbusch, \& Renner, 2002). In contrast to the observational studies that focus on corruption perceptions, experimental research tends to focus on corrupt transactions. Like other experimental work in the social sciences, external validity is a perennial concern and carefully designed observational studies can complement and increase our confidence in their findings. Second, several scholars argue that it is now possible to collect reliable micro-data on corrupt activities from well-designed surveys (see for example Diaby \& Sylwester, 2015). According to Reinikka and Svensson (2006, p. 365) reliable surveys should use indirect questions to encourage truthful responses and avoid incriminating the respondent. Since the advent of this type of survey technique in corruption research, there has been a plethora of new studies exploring corrupt activities in different contexts, including bribery in Asian firms $(\mathrm{Wu}, 2009)$, how the gender of top management affects bribery (Breen, Gillanders, McNulty, \& Suzuki, 2017), how bribery affects firm growth (Fisman \& Svensson, 2007), and how males and younger people are more likely to pay bribes in sub-Saharan Africa (Justesen \& Bjørnskov, 2014). Finally, a new wave of corruption research is developing new approaches using machine learning techniques (Hlatshwayo et al., 2018) and novel data, including public procurement data (Fazekas, Tóth, \& King, 2016) and audit results (Mondo, 2016).

We draw several lessons from the wider literature on corruption measurement. The first is that there is no single optimal approach to measuring corruption outcomes and that each of the existing approaches have limitations and advantages. The second is that advances in survey design mean that we can now construct reliable measures of corruption experiences from sources such as the World Bank's Enterprise surveys. Thus, it is now possible to test the relationship between corruption perceptions and press freedom whilst holding corruption experiences constant. Moreover, it is possible to examine the circumstances under which the reputational premium may be stronger or weaker. To do so, we estimate models which incorporate measures of experienced and perceived levels of corruption, as well as interaction terms between press freedom and experienced-based measures of corruption. Our data, methods and findings are described in the sections that follow.

\section{Data and Method}

We measure press freedom using Freedom House's index. Freedom House create their index by combining expert assessments with analyses of newspapers, and government and non-government documents. One of the advantages of this index is that it places an emphasis on the implementation of press freedom, as well as taking into consideration laws and practices. Implementation matters: Though a free press may be enshrined in legislation it may not be implemented in practice, underlining the need for broad measures that capture de facto as well as de jure press freedom. The index ranges from 0 to 100 with larger numbers denoting less press freedom. Table 1 presents summary statistics for our key variables and Table 2 shows their correlations. In our sample, Sweden in 2014 has the most press freedom with a score of 10. Uzbekistan in 2013 scored 95 and is the country with the least press freedom in our sample. Despite the advantages of Freedom House's indicator, it may be subject to perception biases. As a robustness test, therefore, we use an alternative metric of press freedom created by Reporters Without Borders. This indicator is compiled from surveys of experts and objective data on journalists' experiences of abuse and violence. It ranges from 0 to 100 , with zero being the best possible score. While neither press freedom indicator is perfect, our results hold across both indicators and their different methodologies, with one placing emphasis on implementation and the other on journalists' experiences of violence. 
Table 1. Data and summary statistics for main sample.

\begin{tabular}{lccccccl}
\hline Variable & $\mathrm{N}$ & Mean & Std. Dev. & Min & Max & Scale & Source \\
\hline Corruption Perceptions Index & 76 & 35.65 & 13.53 & 11 & 87 & $0-100$ & $\begin{array}{l}\text { Transparency } \\
\text { International (2019) }\end{array}$ \\
Bribery Index & 76 & 16.33 & 14.19 & 0 & 61.8 & \% Firms & World Bank (2019a) \\
Obstacle & 76 & 7.36 & 5.79 & 0 & 23.6 & \% Firms & World Bank (2019a) \\
Press Freedom & 76 & 54.44 & 19.51 & 10 & 95 & $0-100$ & Freedom House (2019) \\
Democracy & 76 & 4.15 & 5.49 & -9 & 10 & -10 to 10 & Beck, Clarke, Groff, Keefer, \\
& 76 & 7.94 & 1.19 & 5.49 & 10.88 & Log & World Bank (2019b) \\
Ln(GDP p.c.) & 76 & -0.18 & 0.47 & -1.49 & 0.75 & Log & World Bank (2019b) \\
Ln(Openness) & & & & & & &
\end{tabular}

To measure corruption perceptions, we use the Transparency International's Corruption Perceptions Index. The index ranges from 0 to 100 , with smaller numbers denoting more corruption. The Corruption Perceptions Index is an amalgamation of several surveys of experts and senior business leaders. It is not correct to compare values of the Corruption Perceptions Index before 2012 due to the way in which the index was constructed before a change in methodology in 2012 and so our sample covers 2012-2016. In a robustness exercise we use the World Bank's Control of Corruption index. Unlike the Corruption Perceptions Index, this is a hybrid indicator as some of its sources are based on individuals' and firms' experiences. Nevertheless, using this variable significantly increases the number of observations.

We source our objective measures of corruption from the World Bank's Enterprise Surveys. These representative surveys of firms have been carried out in many countries by a specialized unit within the World Bank since the early years of the millennium. The respondents are owners and top managers of private firms, with a focus on the manufacturing and service sectors. From the resulting dataset, we draw on two variables to measure the experienced level of corruption. The first is the percentage of public transactions in which a gift or informal payment was requested. This is created from six survey questions which ask respondents if 'an informal gift or payment expected or requested' in the contexts of seeking electrical or water connections, construction, import, and operating licenses and permits, and meeting with tax officials. Many of the same authors who have identified concerns with regards to using perceptions of corruption as a proxy for the reality of corruption have argued that exercises like the World Bank's Enterprise Surveys can provide reliable information on corruption (Knack, 2007; Reinikka \& Svensson, 2006; Svensson, 2005). In our main sample, this bribery index ranges from $0 \%$ in Estonia and Israel in 2013 to $61.8 \%$ in Cambodia in the same year with a mean of around $16 \%$. Our second measure-obstacleis the percentage of firms who identify corruption as the biggest obstacle they face. Together, these measures capture firms' experiences of corruption, though the first more directly measures firms' broad experiences while the second is useful because it addresses the extent to which corruption matters in a hierarchy of challenges. Mawejje and Sebudde (2019) have tested the validity of the second measure in a study of Ugandan firms, finding a negative correlation between obstacle and expectations regarding future firm performance. Figure 1 illustrates the relationship between our key variables. The top-left panel plots the simple correlation between the Corruption Perceptions Index and press freedom, and shows that more press freedom is associated with a lower level of perceived corruption. The top-right panel plots the objective measure of corruption-our bribery index-against press freedom. In line with Binhadab et al. (2018), it suggests that more press freedom is associated with less experienced corruption. The bottom panel of Figure 1 plots perceptions of corruption against firms' experiences of corruption and finds a moderate correla-

Table 2. Correlation matrix.

\begin{tabular}{|c|c|c|c|c|c|c|}
\hline & Bribery index & Obstacle & Press freedom & Democracy & Log GDP pc & Log openness \\
\hline Corruption Perceptions Index & 1.00 & & & & & \\
\hline Bribery Index & -0.57 & 1.00 & & & & \\
\hline Obstacle & -0.37 & 0.46 & 1.00 & & & \\
\hline Press Freedom & -0.72 & 0.36 & 0.09 & 1.00 & & \\
\hline Democracy & 0.53 & -0.20 & 0.06 & -0.77 & 1.00 & \\
\hline Log GDP pc & 0.71 & -0.56 & -0.25 & -0.46 & 0.32 & 1.00 \\
\hline Log Openness & 0.34 & -0.05 & -0.19 & -0.22 & 0.14 & 0.25 \\
\hline
\end{tabular}



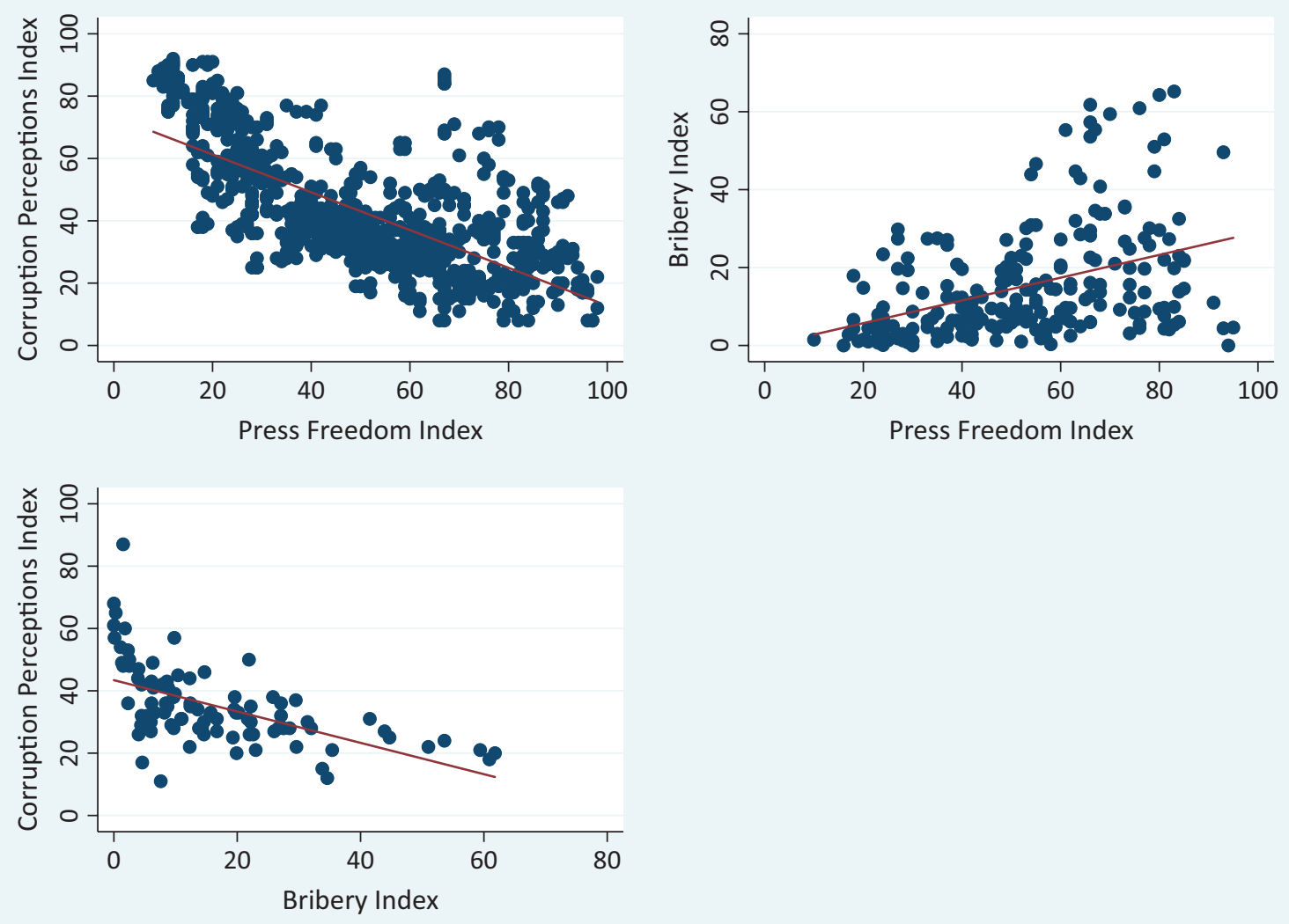

Figure 1. Relationships between main variables.

tion between the two (-0.57). Previous studies have considered the association between corruption experiences and perceptions. Treisman (2007) demonstrates that, controlling for national income, many factors that predict perceptions of corruption do not predict experiencebased metrics. Gillanders and Parviainen (2018) show that perceptions, not experiences, predict foreign direct investment inflows. In the context of our study, the lack of a very strong correlation suggests that factors such as press freedom could influence perceptions of corruption more, or indeed less, than the reality of corruption.

As an alternative to the bribery index, in some specifications we include the percentage of firms who view corruption to be a major constraint in terms of their current operations. While this is a measure of perceptions in a sense, it is measuring the perceptions of people directly affected by corruption. It also has the advantage of allowing for additional modalities of corruption as it does not simply ask about bribery.

Our approach is to follow Brunetti and Weder (2003) and estimate simple regression models in which corruption perceptions are explained by press freedom. While we do have some countries with repeated observations of the bribery index, there is little time variation within press freedom. Indeed, the correlation between press freedom and its 10th lag is 0.95 . Therefore, our key innovation is to control for objectively measured corruption in order to examine if press freedom is associated with perceptions of corruption holding the reality of corruption constant. Our basic regression of interest is:

$$
\begin{aligned}
& \text { Corruption Perceptions Index } i= \\
& \qquad=\alpha+\beta_{1} P F_{i}+\beta_{2} E_{X P_{i}}+\beta_{x} X_{i}+\varepsilon_{i}
\end{aligned}
$$

where Corruption Perceptions Index $i$ is the corruption score given to country $i$ by Transparency International's Corruption Perceptions Index; $P F_{i}$ is the level of press freedom of country $i$; EXP $P_{i}$ is the country's experience of corruption; $X_{i}$ represents the control variables; and $\varepsilon_{i}$ is an error term of the usual type.

Our control variables include factors that are commonly included as controls in regressions seeking to explain corruption, namely the level of democracy as measured by the Polity IV database and GDP per capita from the World Development Indicators. In addition, we use openness to international trade, measured as exports plus imports divided GDP, also from the World Development Indicators. Each of these could plausibly influence press freedom and both corruption perceptions and experiences. Triesman (2000) argues that democracy increases the risk of acting corruptly, in part through freedom of the press. Chowdhury (2004) finds that democracy predicts less corruption, holding press freedom constant. Kalenborn and Lessmann (2013) present evidence that press freedom and democracy are complimentary with both needed to reduce corruption. Gundlach and 
Paldam (2009) provide evidence that economic development causes less corruption. In our tests that replicate Brunetti and Weder's (2003) basic specification, we control for openness to international trade as a measure of competition (Ades \& Di Tella, 1999; Triesman, 2007).

\section{Results}

\subsection{Press Freedom and Corruption Perceptions}

Before testing for a reputational premium we corroborate Brunetti and Weder's (2003) original finding using contemporary data. We employ the Corruption Perceptions Index as our main measure of corruption perceptions as opposed to the International Country Risk Guide. Brunetti and Weder (2003) show that their results are robust to using the Corruption Perceptions Index. Table 3 presents these estimates. Column 1 shows pooled estimates from 2012-2016, adjusting for the level of democracy, GDP per capita, and openness to international trade. All of these variables are statistically significant predictors of corruption perceptions, as is press freedom. Column 2 adds year fixed effects and shows that nothing changes in terms of statistical significance or the magnitude of the coefficients. As already noted, there is very little variation in press freedom over time. Nevertheless, for complete- ness, column 3 reports estimates from fixed effects regressions to account for long-term historical factors and trends. While the sign of the coefficient on press freedom is in the expected direction it is not statistically significant. This is in line with Kalenborn and Lessmann (2013) who emphasize the lack of within country variation in such data. While the assumption for random effects may not be valid as the country specific effect is plausibly correlated with the independent variables, we nonetheless follow the literature and present results using random effects (Brunetti \& Weder, 2003; Chowdhury, 2004; Kalenborn \& Lessmann, 2013). As shown by Papyrakis, Rieger, and Gilberthorpe (2017), there is some trade-off for variables that are 'sluggish' (i.e., they do not vary considerably over-time). In such instances the fixed effects regression model can be highly susceptible to type II errors and random effects estimators' absolute bias may even be smaller. Column 4 presents these results which again point to a significant association between press freedom and corruption perceptions. These models, which corroborate Brunetti and Weder (2003), are based on 668 observations from 2012-2016, while our later results which control for corruption experiences are based on a smaller sample of 76 observations from 2012-2016. There are fewer observations in the latter sample due to the more periodic nature of the World Bank's Enterprise Surveys.

Table 3. Corruption perceptions and press freedom.

\begin{tabular}{|c|c|c|c|c|c|c|c|c|c|c|}
\hline Variable & $\begin{array}{l}(1) \\
\text { OLS }\end{array}$ & $\begin{array}{l}(2) \\
\text { OLS }\end{array}$ & $\begin{array}{l}(3) \\
F E\end{array}$ & $\begin{array}{l}(4) \\
\mathrm{RE}\end{array}$ & $\begin{array}{l}\text { (5) } \\
\text { OLS }\end{array}$ & $\begin{array}{l}(6) \\
\text { OLS }\end{array}$ & $\begin{array}{l}(7) \\
\text { OLS }\end{array}$ & $\begin{array}{l}\text { (8) } \\
\text { OLS }\end{array}$ & $\begin{array}{l}\text { (9) } \\
\text { OLS }\end{array}$ & $\begin{array}{l}\text { (10) } \\
\text { OLS }\end{array}$ \\
\hline $\begin{array}{l}\text { Press } \\
\text { Freedom }\end{array}$ & $\begin{array}{c}-0.50 * * * \\
(0.031)\end{array}$ & $\begin{array}{c}-0.50 * * * \\
(0.031)\end{array}$ & $\begin{array}{l}-0.07 \\
(0.052)\end{array}$ & $\begin{array}{c}-0.19 * * * \\
(0.049)\end{array}$ & $\begin{array}{c}-0.50 * * * \\
(0.071)\end{array}$ & $\begin{array}{c}-0.49 * * * \\
(0.067)\end{array}$ & $\begin{array}{c}-0.51 * * * \\
(0.068)\end{array}$ & $\begin{array}{c}-0.49 * * * \\
(0.073)\end{array}$ & $\begin{array}{c}-0.50 * * * \\
(0.068)\end{array}$ & $\begin{array}{c}-0.40 * * * \\
(0.033)\end{array}$ \\
\hline Democracy & $\begin{array}{c}-0.60 * * * \\
(0.096)\end{array}$ & $\begin{array}{c}-0.60 * * * \\
(0.097)\end{array}$ & $\begin{array}{l}-0.07 \\
(0.178)\end{array}$ & $\begin{array}{l}-0.08 \\
(0.147)\end{array}$ & $\begin{array}{c}-0.61^{* *} \\
(0.260)\end{array}$ & $\begin{array}{c}-0.65^{* * *} \\
(0.221)\end{array}$ & $\begin{array}{c}-0.66 * * * \\
(0.207)\end{array}$ & $\begin{array}{c}-0.53^{* *} \\
(0.217)\end{array}$ & $\begin{array}{c}-0.57^{* * *} \\
(0.201)\end{array}$ & $\begin{array}{c}-0.41 * * * \\
(0.096)\end{array}$ \\
\hline $\begin{array}{l}\text { Ln(GDP per } \\
\text { capita) }\end{array}$ & $\begin{array}{l}6.74 * * * \\
(0.304)\end{array}$ & $\begin{array}{l}6.73^{* * *} \\
(0.305)\end{array}$ & $\begin{array}{c}6.15^{* *} \\
(2.355)\end{array}$ & $\begin{array}{l}8.45^{* * *} \\
(0.703)\end{array}$ & $\begin{array}{l}6.66 * * * \\
(0.732)\end{array}$ & $\begin{array}{l}7.34 * * * \\
(0.648)\end{array}$ & $\begin{array}{l}6.90 * * * \\
(0.624)\end{array}$ & $\begin{array}{l}6.46^{* * *} \\
(0.710)\end{array}$ & $\begin{array}{l}6.30 * * * \\
(0.717)\end{array}$ & $\begin{array}{l}6.74 * * * \\
(0.457)\end{array}$ \\
\hline Ln(Openness) & $\begin{array}{l}2.36 * * * \\
(0.814)\end{array}$ & $\begin{array}{l}2.36^{* * *} \\
(0.817)\end{array}$ & $\begin{array}{l}-1.51 \\
(1.627)\end{array}$ & $\begin{array}{l}-0.16 \\
(1.440)\end{array}$ & $\begin{array}{c}2.25 \\
(1.667)\end{array}$ & $\begin{array}{c}2.70 \\
(1.737)\end{array}$ & $\begin{array}{c}2.69 \\
(1.765)\end{array}$ & $\begin{array}{c}2.34 \\
(2.011)\end{array}$ & $\begin{array}{c}1.83 \\
(2.087)\end{array}$ & $\begin{array}{c}2.05 * * \\
(0.811)\end{array}$ \\
\hline OECD & & & & & & & & & & $\begin{array}{l}5.73 * * * \\
(1.396)\end{array}$ \\
\hline $\begin{array}{l}\text { sub-Saharan } \\
\text { Africa }\end{array}$ & & & & & & & & & & $\begin{array}{c}3.08 * * * \\
(1.113)\end{array}$ \\
\hline $\begin{array}{l}\text { Latin America } \\
\text { \& Caribbean }\end{array}$ & & & & & & & & & & $\begin{array}{c}-4.29 * * * \\
(1.108)\end{array}$ \\
\hline Constant & $\begin{array}{l}13.93 * * * \\
(3.781)\end{array}$ & $\begin{array}{l}13.74 * * * \\
(3.821)\end{array}$ & $\begin{array}{l}-4.98 \\
(21.207)\end{array}$ & $\begin{array}{c}-19.07 * * * \\
(7.314)\end{array}$ & $\begin{array}{l}15.11^{*} \\
(9.072)\end{array}$ & $\begin{array}{c}8.99 \\
(8.221)\end{array}$ & $\begin{array}{l}13.62^{*} \\
(7.856)\end{array}$ & $\begin{array}{l}15.18^{*} \\
(8.856)\end{array}$ & $\begin{array}{c}17.44 * * \\
(8.606)\end{array}$ & $\begin{array}{c}6.37 \\
(4.958)\end{array}$ \\
\hline $\begin{array}{l}\text { Year fixed } \\
\text { effects }\end{array}$ & No & Yes & Yes & Yes & n.a. & n.a. & n.a. & n.a. & n.a. & Yes \\
\hline $\begin{array}{l}\text { Restricted } \\
\text { sample }\end{array}$ & No & No & No & No & 2016 & 2015 & 2014 & 2013 & 2012 & No \\
\hline Observations & 668 & 668 & 668 & 668 & 121 & 133 & 137 & 139 & 138 & 668 \\
\hline R-squared & 0.762 & 0.762 & 0.667 & 0.718 & 0.789 & 0.779 & 0.775 & 0.740 & 0.735 & 0.784 \\
\hline
\end{tabular}


While Transparency International changed their methodology in 2012, and argue that one can meaningfully compare data over time thereafter, the fact that data sources for the Corruption Perceptions Index can change from year to year is a concern, particularly given that our main results are based on a sample in which we have observations from different countries in different years. It is reassuring, therefore, that our findings hold in separate tests where the sample is limited to a single year from the period 2012-2016. These tests, displayed in columns 5 to 9 , show that the results are consistent in terms of statistical significance and magnitude. Finally, in Column 10, we emulate Brunetti and Weder (2003) and include dummies for the OECD, Latin American and Caribbean, and sub-Saharan Africa to allow for unobserved heterogeneity between these groups (and the rest of the world as the omitted category). Our findings are robust to this modification, and Column 10 serves as our baseline model to which we will now add corruption experiences.

\subsection{The Reputational Premium Hypothesis}

Table 4 presents our results which adjust for corruption experiences using World Bank's Enterprise Survey data. As these are not carried out in each country each year, we have a smaller sample when the corresponding variable is included in our tests. Column 1 shows that press freedom is nonetheless associated with corruption perceptions in this smaller sample. Column 2 presents our main finding. It shows that after controlling for the incidence of bribery in public transactions, which is a significant predictor of corruption perceptions in our sample, press freedom remains a significant predictor of corruption perceptions. Moreover, the estimated coefficient only falls slightly relative to column 1 . In terms of the substantive relationship, the findings indicate that a onepoint increase in press freedom improves corruption perceptions by 0.27 of a unit on the Corruption Perceptions Index. As we already mentioned above, both of these scales run from 0-100. The magnitude of this association is similar (0.24) when the bribery index is included in column 2. Here, a $1 \%$ improvement in the bribery index is associated with a 0.22 improvement in the Corruption Perceptions Index.

Column 3 reaches the same conclusion, presenting estimates using an alternative objective measure of corruption, the percentage of firms who report that corruption is an impediment to their operations. Column 4 includes both of these variables in the same model, and shows that press freedom remains statistically significant. The remaining columns repeat this analysis using alternative measures of press freedom. Column 5 uses Freedom House's categorization of press freedom as 'Free,' 'Partly free,' and 'Not free' instead of the continuous measure. Controlling for corruption experiences,

Table 4. Inclusion of corruption experiences.

\begin{tabular}{|c|c|c|c|c|c|c|c|c|}
\hline Variables & (1) & (2) & (3) & (4) & (5) & (6) & (7) & (8) \\
\hline Press freedom & $\begin{array}{c}-0.27 * * * \\
(0.070)\end{array}$ & $\begin{array}{c}-0.24 * * * \\
(0.074)\end{array}$ & $\begin{array}{c}-0.26^{* * *} \\
(0.064)\end{array}$ & $\begin{array}{c}-0.25^{* * *} \\
(0.069)\end{array}$ & & & & \\
\hline $\begin{array}{l}\text { Press freedom } \\
\text { (Reporters Without } \\
\text { Borders Rank) }\end{array}$ & & & & & & $\begin{array}{c}-0.08 * * \\
(0.032)\end{array}$ & $\begin{array}{c}-0.09 * * * \\
(0.029)\end{array}$ & $\begin{array}{c}-0.07^{* *} \\
(0.030)\end{array}$ \\
\hline Not free & & & & & $\begin{array}{c}-9.42^{* * *} \\
(3.070)\end{array}$ & & & \\
\hline Partly free & & & & & $\begin{array}{c}-6.62 * * \\
(2.650)\end{array}$ & & & \\
\hline Bribery index & & $\begin{array}{c}-0.22 * * * \\
(0.070)\end{array}$ & & $\begin{array}{c}-0.16^{* *} \\
(0.073)\end{array}$ & $\begin{array}{c}-0.16 * * \\
(0.076)\end{array}$ & $\begin{array}{c}-0.20 * * * \\
(0.070)\end{array}$ & & $\begin{array}{c}-0.14^{*} \\
(0.077)\end{array}$ \\
\hline Obstacle & & & $\begin{array}{c}-0.45^{* *} \\
(0.176)\end{array}$ & $\begin{array}{c}-0.33^{*} \\
(0.177)\end{array}$ & $\begin{array}{c}-0.26 \\
(0.186)\end{array}$ & & $\begin{array}{c}-0.40 * * \\
(0.172)\end{array}$ & $\begin{array}{l}-0.29 \\
(0.180)\end{array}$ \\
\hline Democracy & $\begin{array}{c}0.09 \\
(0.182)\end{array}$ & $\begin{array}{c}0.16 \\
(0.187)\end{array}$ & $\begin{array}{c}0.21 \\
(0.218)\end{array}$ & $\begin{array}{c}0.23 \\
(0.216)\end{array}$ & $\begin{array}{l}0.60 * * * \\
(0.179)\end{array}$ & $\begin{array}{c}0.42 * * \\
(0.165)\end{array}$ & $\begin{array}{c}0.47^{* *} \\
(0.191)\end{array}$ & $\begin{array}{c}0.49 * * \\
(0.188)\end{array}$ \\
\hline Ln(GDP per capita) & $\begin{array}{l}5.21 * * * \\
(1.032)\end{array}$ & $\begin{array}{l}3.41 * * * \\
(1.177)\end{array}$ & $\begin{array}{l}4.65 * * * \\
(0.826)\end{array}$ & $\begin{array}{l}3.53 * * * \\
(1.118)\end{array}$ & $\begin{array}{l}3.90 * * * \\
(1.155)\end{array}$ & $\begin{array}{c}3.30 * * * \\
(1.133)\end{array}$ & $\begin{array}{l}4.43 * * * \\
(0.897)\end{array}$ & $\begin{array}{c}3.46^{* * *} \\
(1.083)\end{array}$ \\
\hline Ln(Openness) & $\begin{array}{c}2.96^{*} \\
(1.502)\end{array}$ & $\begin{array}{c}3.66 * * \\
(1.411)\end{array}$ & $\begin{array}{c}2.41 \\
(1.583)\end{array}$ & $\begin{array}{c}3.06 * * \\
(1.477)\end{array}$ & $\begin{array}{c}3.12^{*} \\
(1.576)\end{array}$ & $\begin{array}{c}2.03 \\
(1.573)\end{array}$ & $\begin{array}{c}0.74 \\
(1.649)\end{array}$ & $\begin{array}{c}1.58 \\
(1.589)\end{array}$ \\
\hline Year fixed effects & YES & YES & YES & YES & YES & YES & YES & YES \\
\hline Observations & 76 & 76 & 76 & 76 & 76 & 75 & 75 & 75 \\
\hline R-squared & 0.770 & 0.799 & 0.799 & 0.812 & 0.795 & 0.782 & 0.782 & 0.793 \\
\hline
\end{tabular}

Notes: Constant and regional dummies not displayed. Robust standard errors in parentheses, ${ }^{* * *} p<0.01,{ }^{* *} p<0.05,{ }^{*} p<0.1$. 
countries classified as 'Partly free' and 'Not free' are perceived to be more corrupt. Columns 6 to 8 present estimates which include a measure of press freedom created by Reporters Without Borders, and are in line with our findings using the Freedom House data.

Overall, the findings suggest that a free press is good news for a country's reputation, as it drives corruption perceptions above and beyond any effect it has on the reality of corruption. This has important consequences because previous studies show that a country's corruption rank is linked to important social and economic indicators such as interpersonal trust (Banerjee et al., 2015; Seligson, 2002; Uslaner, 2004) and foreign direct investment (Gillanders \& Parviainen, 2018; Wei, 2000). The reputational premium we find is further evidence of the importance of a vibrant public space for the exchange of information and ideas.

\subsection{Reputational Gains and the Level of Corruption}

We now consider which countries stand to gain this reputational premium. One possibility is that countries only gain if they are relatively corruption free. Countries with little actual corruption may not earn a premium because they have already achieved a top reputation, which acts as a ceiling. Alternatively, very corrupt countries may not benefit much from marginal improvements in press freedom, as their poor reputation acts as a floor in corruption ranking exercises. Interestingly, a previous study (Ahrend, 2002) finds that education only reduces corruption where there is press freedom. If a state signals change and initiates the process of liberalization, this might be seen as a signal to corruption experts that the state should get credit from initiating the process of press liberalization. Across these scenarios, experts may overreact or underreact to a state's existing reputation or the signals that it sends about its future path or direction. To test these possibilities, we estimate models including interaction terms between press freedom and the experience-based measures of corruption. Table 5 presents the results. The interaction term in column 1 is statistically significant when we use the bribery incidence variable and is not significant when we use the obstacle variable in its place (column 2). The positive sign

Table 5. Interacting experienced corruption with press freedom.

\begin{tabular}{|c|c|c|}
\hline Variables & (1) & $(2)$ \\
\hline Press freedom & $\begin{array}{c}-0.38 * * * \\
(0.105)\end{array}$ & $\begin{array}{c}-0.35^{* * *} \\
(0.098)\end{array}$ \\
\hline Bribery index & $\begin{array}{c}-0.85^{* *} \\
(0.331)\end{array}$ & \\
\hline Press freedom*Bribery index & $\begin{array}{c}0.01 * * \\
(0.005)\end{array}$ & \\
\hline Obstacle & & $\begin{array}{c}-1.10^{* *} \\
(0.513)\end{array}$ \\
\hline Press freedom*Obstacle & & $\begin{array}{c}0.01 \\
(0.008)\end{array}$ \\
\hline Democracy & $\begin{array}{c}0.16 \\
(0.189)\end{array}$ & $\begin{array}{c}0.18 \\
(0.218)\end{array}$ \\
\hline Ln(GDP per capita) & $\begin{array}{l}3.15^{* * *} \\
(1.097)\end{array}$ & $\begin{array}{l}4.40 * * * \\
(0.861)\end{array}$ \\
\hline Ln(Openness) & $\begin{array}{c}2.51^{*} \\
(1.478)\end{array}$ & $\begin{array}{c}2.38 \\
(1.630)\end{array}$ \\
\hline OECD & $\begin{array}{c}2.08 \\
(3.735)\end{array}$ & $\begin{array}{c}3.07 \\
(3.079)\end{array}$ \\
\hline sub-Saharan Africa & $\begin{array}{l}-0.71 \\
(2.414)\end{array}$ & $\begin{array}{l}-0.45 \\
(2.623)\end{array}$ \\
\hline Latin America \& Caribbean & $\begin{array}{c}-10.92 * * * \\
(2.823)\end{array}$ & $\begin{array}{c}-7.42 * * \\
(2.956)\end{array}$ \\
\hline Constant & $\begin{array}{c}31.29 * * \\
(12.896)\end{array}$ & $\begin{array}{c}19.06^{*} \\
(11.239)\end{array}$ \\
\hline Year fixed effects & YES & YES \\
\hline Observations & 76 & 76 \\
\hline R-squared & 0.811 & 0.805 \\
\hline
\end{tabular}

Notes: Robust standard errors in parentheses, ${ }^{* * *} p<0.01,{ }^{* *} p<0.05,{ }^{*} p<0.1$. 
on this interaction term in column 1 suggests that press freedom is less effective at promoting a good reputation in contexts with more experienced corruption.

To investigate further, the top-left panel of Figure 2 plots the marginal effect of press freedom on corruption perceptions by level of experienced corruption. It shows that the marginal effect of improvements in press freedom declines as the reality of corruption increases but remains statistically significant until around 20 on the bribery index. As we have seen, this level on the index means that $20 \%$ of the transactions in which firms sought utilities' connections or engaged with tax and regulatory authorities featured bribery requests or expectations. The remaining panels of Figure 2 (top-right and bottom) plot the distribution of the bribery index (in 5\% bins) and show that the majority of countries in our sample and in a broader sample not limited to post 2012 observations fall below this threshold. Therefore, the reputational benefits of a free press are not limited to low corruption countries, though such countries do stand to gain the most from marginal improvements in press freedom.

\subsection{Robustness Checks}

Indices such as the Corruption Perceptions Index are designed to reflect perceptions of both grand and petty corruption. However, some may regard firm-level experiences of bribery as petty corruption, though many of the contexts would involve large sums (tax and construction) or occur only once or rarely (for example, in obtaining licenses, permits, and utility connections). To address this concern, we use a proxy for grand corruption-the percentage of firms who express the view that corruption in public procurement is necessary. Corruption in government procurement is generally regarded as one of the main modalities of grand corruption, which lends support to our decision to use this proxy (David-Barrett \& Fazekas, 2019). This proxy, which also comes from the World Bank's Enterprise Surveys, is based on a question where firm owners and managers are asked if other firms with the same characteristics as their own are expected to pay bribes in order to secure government contracts. The assumption here is that firms draw on their own experience when asked about 'firms like this one' or that they are sufficiently well informed or experienced about the workings of procurement processes in their industry to make an accurate determination.

Table 6 presents the results. When our proxy for grand corruption is included, we still find a statistically significant association between press freedom and corruption perceptions. Interestingly, procurement corruption does not have a statistically significant relationship with perceptions of corruption, perhaps reflecting the difficulty for such grand corruption to be observed by external experts and agencies until it is exposed. These results support our contention that there is a reputational
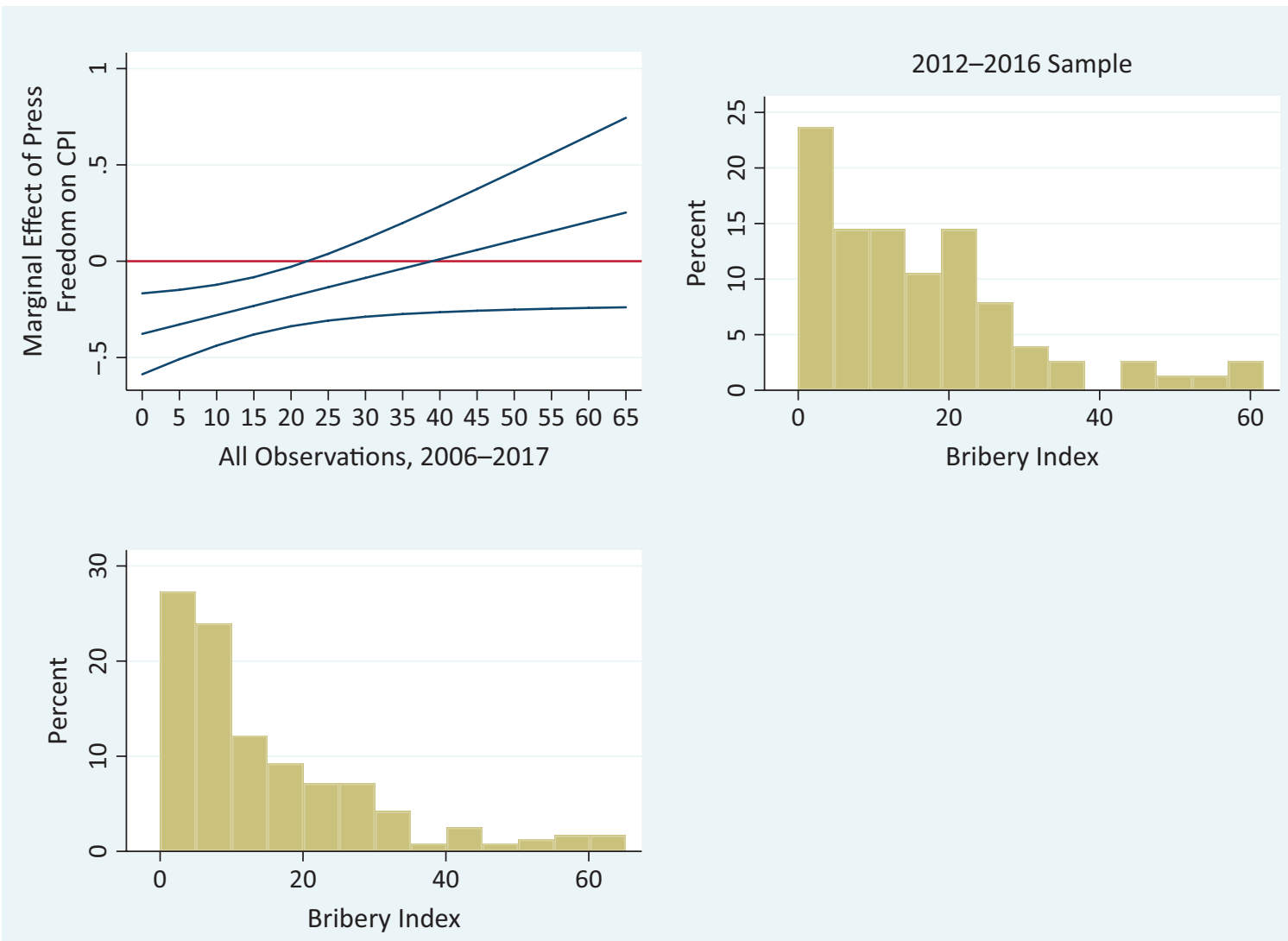

Figure 2. Marginal effect of press freedom by level of experienced corruption. 
Table 6. Controlling for proxy for grand corruption.

\begin{tabular}{|c|c|c|c|}
\hline Variables & (1) & $(2)$ & (3) \\
\hline Press freedom & $\begin{array}{c}-0.27^{* * *} \\
(0.070)\end{array}$ & $\begin{array}{c}-0.25^{* * *} \\
(0.074)\end{array}$ & $\begin{array}{c}-0.26 * * * \\
(0.065)\end{array}$ \\
\hline Bribery index & & $\begin{array}{c}-0.20 * * * \\
(0.062)\end{array}$ & \\
\hline Obstacle & & & $\begin{array}{c}-0.41^{* *} \\
(0.164)\end{array}$ \\
\hline Procurement corruption index & $\begin{array}{c}-0.08 \\
(0.049)\end{array}$ & $\begin{array}{l}-0.03 \\
(0.042)\end{array}$ & $\begin{array}{l}-0.04 \\
(0.044)\end{array}$ \\
\hline Democracy & $\begin{array}{c}0.11 \\
(0.192)\end{array}$ & $\begin{array}{c}0.16 \\
(0.193)\end{array}$ & $\begin{array}{c}0.21 \\
(0.221)\end{array}$ \\
\hline $\operatorname{Ln}(G D P$ p.c.) & $\begin{array}{l}4.35^{* * *} \\
(1.137)\end{array}$ & $\begin{array}{c}3.23 * * \\
(1.222)\end{array}$ & $\begin{array}{l}4.26 * * * \\
(0.985)\end{array}$ \\
\hline Ln(Openness) & $\begin{array}{c}2.70 * \\
(1.566)\end{array}$ & $\begin{array}{c}3.47 * * \\
(1.461)\end{array}$ & $\begin{array}{c}2.33 \\
(1.600)\end{array}$ \\
\hline OECD & $\begin{array}{c}6.51 * * \\
(2.976)\end{array}$ & $\begin{array}{c}5.78^{*} \\
(3.072)\end{array}$ & $\begin{array}{c}4.44 \\
(2.945)\end{array}$ \\
\hline sub-Saharan Africa & $\begin{array}{c}0.74 \\
(2.663)\end{array}$ & $\begin{array}{l}-0.60 \\
(2.533)\end{array}$ & $\begin{array}{l}-0.28 \\
(2.421)\end{array}$ \\
\hline Latin America \& Caribbean & $\begin{array}{c}-9.31 * * * \\
(3.211)\end{array}$ & $\begin{array}{c}-10.42 * * * \\
(3.010)\end{array}$ & $\begin{array}{c}-8.64 * * * \\
(3.028)\end{array}$ \\
\hline Constant & $\begin{array}{c}14.72 \\
(12.770)\end{array}$ & $\begin{array}{c}23.99 * \\
(13.148)\end{array}$ & $\begin{array}{c}16.46 \\
(10.952)\end{array}$ \\
\hline Year fixed effects & YES & YES & YES \\
\hline Observations & 76 & 76 & 76 \\
\hline R-squared & 0.781 & 0.801 & 0.802 \\
\hline
\end{tabular}

Notes: Robust standard errors in parentheses, ${ }^{* * *} p<0.01,{ }^{* *} p<0.05,{ }^{*} p<0.1$.

bounty from a free press on top of any effect on actual corruption levels.

Finally, Table 7 presents the results from running our main models with the World Bank's Control of Corruption index as our measure of corruption perceptions. This indicator ranges from -2.5 to 2.5 , with larger numbers denoting less corruption. As noted above, this metric contains some sources that are based on experiences rather than expert assessments. Nevertheless, it is highly correlated with the Corruption Perceptions Index in our sample (0.98). Using this metric of corruption perceptions does allow us to expand our sample considerably as the control of corruption methodology has not changed as dramatically as the Corruption Perceptions Index methodology has, though the authors do note that changes in score can reflect changes in sources or weighting (Kaufmann, Kraay, \& Mastruzzi, 2011). Columns 1 to 3 of Table 7 shows that our conclusion regarding the reputational benefit of a free press is robust to this change in dependent variable, with the only substantial difference being that procurement corruption is associated with perceptions of corruption in this larger sample.

\section{Conclusions}

In this article, we explore whether cross-country corruption perception indices based on expert assessments reward states with a freer press more than one might expect given levels of experienced corruption. We find that press freedom improves a country's reputation, creating a reputational premium. In other words, whilst a free press may reduce corrupt behavior directly, we find that it also reduces corruption perceptions, irrespective of actual corruption levels. In particular, we find that the developed world is the main beneficiary of this reputational premium, as it is strongest in countries with low to moderate levels of corruption by global standards. These findings are robust to several concerns regarding corruption measurement. One concern is that our measure of corruption experiences is biased toward petty corruption because it is compiled from firm-level surveys. To address this concern, we repeated our tests using a proxy for grand corruption. We also used alternative measures of press freedom, corruption perceptions, and corruption experiences. Our findings using these alternative measures and proxy variable were in line with our main results. 
Table 7. Robustness: Key results using World Bank's Control of Corruption index.

\begin{tabular}{|c|c|c|c|}
\hline Variables & (1) & $(2)$ & (3) \\
\hline Press freedom & $\begin{array}{c}-0.02 * * * \\
(0.003)\end{array}$ & $\begin{array}{c}-0.02 * * * \\
(0.002)\end{array}$ & $\begin{array}{c}-0.01 * * * \\
(0.002)\end{array}$ \\
\hline Bribery index & & $\begin{array}{c}-0.01 * * * \\
(0.003)\end{array}$ & $\begin{array}{c}-0.01 * * * \\
(0.003)\end{array}$ \\
\hline Procurement corruption index & & & $\begin{array}{c}-0.01 * * * \\
(0.002)\end{array}$ \\
\hline Democracy & $\begin{array}{c}-0.01 \\
(0.008)\end{array}$ & $\begin{array}{l}-0.01 \\
(0.007)\end{array}$ & $\begin{array}{c}-0.01 \\
(0.007)\end{array}$ \\
\hline Ln(GDP per capita) & $\begin{array}{c}0.22^{* * *} \\
(0.038)\end{array}$ & $\begin{array}{c}0.13^{* * *} \\
(0.040)\end{array}$ & $\begin{array}{c}0.13^{* * *} \\
(0.040)\end{array}$ \\
\hline Ln(Openness) & $\begin{array}{c}0.02 \\
(0.068)\end{array}$ & $\begin{array}{c}0.06 \\
(0.064)\end{array}$ & $\begin{array}{c}0.03 \\
(0.067)\end{array}$ \\
\hline OECD & $\begin{array}{c}0.31 * * \\
(0.141)\end{array}$ & $\begin{array}{c}0.29 * * \\
(0.136)\end{array}$ & $\begin{array}{c}0.30 * * \\
(0.130)\end{array}$ \\
\hline sub-Saharan Africa & $\begin{array}{c}0.11 \\
(0.093)\end{array}$ & $\begin{array}{l}-0.00 \\
(0.091)\end{array}$ & $\begin{array}{c}0.01 \\
(0.091)\end{array}$ \\
\hline Latin America \& Caribbean & $\begin{array}{l}-0.21 \\
(0.145)\end{array}$ & $\begin{array}{c}-0.42^{* * *} \\
(0.145)\end{array}$ & $\begin{array}{c}-0.45^{* * *} \\
(0.143)\end{array}$ \\
\hline Constant & $\begin{array}{c}-1.01^{* *} \\
(0.395)\end{array}$ & $\begin{array}{l}-0.10 \\
(0.413)\end{array}$ & $\begin{array}{l}-0.04 \\
(0.426)\end{array}$ \\
\hline Year fixed effects & YES & YES & YES \\
\hline Observations & 193 & 193 & 190 \\
\hline R-squared & 0.610 & 0.671 & 0.688 \\
\hline
\end{tabular}

Notes: Robust standard errors in parentheses, ${ }^{* * *} \mathrm{p}<0.01,{ }^{* *} \mathrm{p}<0.05,{ }^{*} \mathrm{p}<0.1$.

Overall, our findings suggest that press freedom has important consequences for a country's standing in international corruption indicators. Previous research shows that these indicators, though they have limitations and may not always capture reality, have real consequences for national wellbeing in terms of attracting foreign direct investment and other important social and economic outcomes. Therefore, policy makers should devote considerable efforts and resources to protecting press freedom where it already exists. Even in countries with a long and venerable tradition of press freedom, more can be done to enshrine its practice in legislation, support the social norms that allow it to function effectively, ensure diversity in the ownership of the media, and strengthen citizens' capacity to act on the information provided by a free press.

Finally, our work contributes to a growing literature which has established a robust and direct link between press freedom and corruption outcomes (Adsera et al., 2003; Brunetti \& Weder, 2003; Freille et al., 2007). In recent years, this literature has expanded to consider a range of corruption and anti-corruption efforts beyond a singular focus on expert perceptions. Binhadab et al. (2018), for example, consider corruption in business and Mungiu-Pippidi and Dadašov (2017) consider the role of press freedom in ensuring the effectiveness of anticorruption laws and tools in different contexts. A promising new line of future research is to compare and contrast multiple corruption indicators and the extent to which they are interrelated, as Adhikari, Breen, and Gillanders (2019) do with firms' and experts' perceptions and Flavin and Montgomery (2019) do with citizens' and experts' perceptions.

\section{Acknowledgments}

The authors are grateful to Nouf Binhadab.

\section{Conflict of Interests}

The authors declare no conflict of interests.

\section{References}

Abbink, K., Irlenbusch, B., \& Renner, E. (2002). An experimental bribery game. Journal of Law, Economics, and Organization, 18(2), 428-454.

Ades, A., \& Di Tella, R. (1999). Rents, competition, and corruption. American Economic Review, 89(4), 982-993.

Adhikari, T., Breen, M., \& Gillanders, R. (2019). Are new states more corrupt? Expert opinions versus 
firms' experiences. Applied Economics Letters, 26(2), 131-134.

Adsera, A., Boix, C., \& Payne, M. (2003). Are you being served? Political accountability and quality of government. Journal of Law, Economics, and Organization, 19(2), 445-490.

Ahrend, R. (2002). Press freedom, human capital, and corruption (Working Paper 2002-11). Paris: DELTA.

Anderson, C. J., \& Tverdova, Y. V. (2003). Corruption, political allegiances, and attitudes toward government in contemporary democracies. American Journal of Political Science, 47(1), 91-109.

Armantier, O., \& Boly, A. (2011). A controlled field experiment on corruption. European Economic Review, 55(8), 1072-1082.

Banerjee, A., Duflo, E., Glennerster, R., \& Kinnan, C. (2015). The miracle of microfinance? Evidence from a randomized evaluation. American Economic Journal: Applied Economics, 7(1), 22-53.

Becker, G. S. (1968). Crime and punishment: An economic approach. Journal of Political Economy, 76(2), 169-217.

Beck, T., Clarke G., Groff A., Keefer P., \& Walsh, P. (2001). New tools in comparative political economy: The Database of Political Institutions. World Bank Economic Review, 15(1), 165-176.

Binhadab, N., Breen, M., \& Gillanders, R. (2018). The role of a free press in combating business corruption (MPRA Paper No. 88954). Munich: University Library of Munich.

Breen, M., Gillanders, R., McNulty, G., \& Suzuki, A. (2017). Gender and corruption in business. Journal of Development Studies, 53(9), 1486-1501.

Brunetti, A., \& Weder, B. (2003). A free press is bad news for corruption. Journal of Public Economics, 87(7), 1801-1824.

Chang, E. C., \& Chu, Y. H. (2006). Corruption and trust: Exceptionalism in Asian democracies? Journal of Politics, 68(2), 259-271.

Charron, N. (2009). The impact of socio-political integration and press freedom on corruption. Journal of Development Studies, 45(9), 1472-1493.

Chowdhury, S. K. (2004). The effect of democracy and press freedom on corruption: An empirical test. Economics Letters, 85(1), 93-101.

David-Barrett, E., \& Fazekas, M. (2019). Grand corruption and government change: An analysis of partisan favoritism in public procurement. European Journal on Criminal Policy and Research. https://doi.org/ 10.1007/s10610-019-09416-4

Diaby, A., \& Sylwester, K. (2015). Corruption and market competition: Evidence from post-communist countries. World Development, 66(2), 487-499.

Fan, C. S., Lin, C., \& Treisman, D. (2009). Political decentralization and corruption: Evidence from around the world. Journal of Public Economics, 93(1/2), 14-34.

Färdigh, M. A., Andersson, E., \& Oscarsson, H. (2011). Re-examining the relationship between press free- dom and corruption (QoG Working Paper Series 13). Gothenburg: University of Gothenburg.

Fazekas, M., Tóth, I. J., \& King, L. P. (2016). An objective corruption risk index using public procurement data. European Journal on Criminal Policy and Research, 22(3), 369-397.

Fisman, R., \& Svensson, J. (2007). Are corruption and taxation really harmful to growth? Firm level evidence. Journal of Development Economics, 83(1), 63-75.

Flavin, P., \& Montgomery, F. (2019). Freedom of the press and perceptions about government corruption. International Political Science Review. https:// doi.org/10.1177/0192512119858469

Freedom House. (2019). Freedom in the World 2019. Washington, DC: Freedom House.

Freille, S., Haque, M. E., \& Kneller, R. (2007). A contribution to the empirics of press freedom and corruption. European Journal of Political Economy, 23(4), 838-862.

Gillanders, R., \& Parviainen, S. (2018). Corruption and the shadow economy at the regional level. Review of Development Economics, 22(4), 1729-1743.

Gundlach, E., \& Paldam, M. (2009). The transition of corruption: From poverty to honesty. Economics Letters, 103(3), 146-148.

Hlatshwayo, S., Oeking, A., Ghazanchyan, M. M., Corvino, D., Shukla, A., \& Leigh, M. L. Y. (2018). The measurement and macro-relevance of corruption: A Big Data approach. Washington, DC: International Monetary Fund.

Justesen, M. K., \& Bjørnskov, C. (2014). Exploiting the poor: Bureaucratic corruption and poverty in Africa. World Development, 58, 106-115.

Kalenborn, C., \& Lessmann, C. (2013). The impact of democracy and press freedom on corruption: Conditionality matters. Journal of Policy Modeling, 35(6), 857-886.

Kaufmann, D., Kraay, A., \& Mastruzzi, M. (2011). The worldwide governance indicators: Methodology and analytical issues. Hague Journal on the Rule of Law, 3(2), 220-246.

Knack, S. (2007). Measuring corruption: A critique of indicators in Eastern Europe and Central Asia. Journal of Public Policy, 27(3), 255-291.

Mauro, P. (1995). Corruption and growth. Quarterly Journal of Economics, 110(3), 681-712.

Mawejje, J., \& Sebudde, R. K. (2019). Constraints or complaints? Business climate and firm performance perceptions in Uganda. Journal of Development Studies, 55(12), 2513-2525.

Mondo, B. V. (2016). Measuring political corruption from audit results: A new panel of Brazilian municipalities. European Journal on Criminal Policy and Research, 22(3), 477-498.

Mosley, L. (2003). Global capital and national governments. Cambridge: Cambridge University Press.

Mungiu-Pippidi, A., \& Dadašov, R. (2017). When do anticorruption laws matter? The evidence on public in- 
tegrity enabling contexts. Crime Law \& Social Change, 68, 387-402.

Papyrakis, E., Rieger, M., \& Gilberthorpe, E. (2017). Corruption and the extractive industries transparency initiative. Journal of Development Studies, 53(2), 295-309.

Reinikka, R., \& Svensson, J. (2006). Using micro-surveys to measure and explain corruption. World Development, 34(2), 359-370.

Seligson, M. A. (2002). The impact of corruption on regime legitimacy: A comparative study of four Latin American countries. Journal of Politics, 64(2), 408-433.

Svensson, J. (2003). Who must pay bribes and how much? Evidence from a cross section of firms. Quarterly Journal of Economics, 118, 207-230.

Svensson, J. (2005). Eight questions about corruption. Journal of Economic Perspectives, 19(3), 19-42.

Transparency International. (2019). Corruption Percep- tions Index. Berlin: Transparency International.

Treisman, D. (2007). What have we learned about the causes of corruption from ten years of cross-national empirical research? Annual Review of Political Science, 10(1), 211-244.

Uslaner, E. M. (2004). Trust and corruption. In J. G. Lambsdorff, M. Taube, \& M. Schramm (Eds.), The new institutional economics of corruption (pp. 90-106). London and New York, NY: Routledge.

Wei, S. J. (2000). How taxing is corruption on international investors? Review of Economics and Statistics, 82(1), 1-11.

World Bank. (2019a). Enterprise surveys. Washington, DC: World Bank.

World Bank. (2019b). World Development Indicators. Washington, DC: World Bank.

Wu, X. (2009). Determinants of bribery in Asian firms: Evidence from the world business environment survey. Journal of Business Ethics, 87(1), 75-88.

\section{About the Authors}

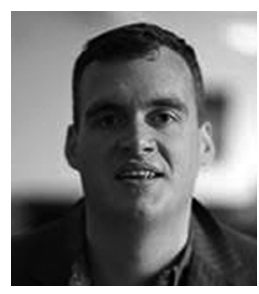

Michael Breen (PhD) is Associate Professor of Politics at Dublin City University, Ireland. He is Co-Director of DCU's Anti-Corruption Research Centre (ARC). His main research interests are in political economy and international relations, with a particular focus on international institutions, and corruption and governance. He has published many articles on corruption, including a recent article in the Journal of Development Studies on gender and corruption in business.

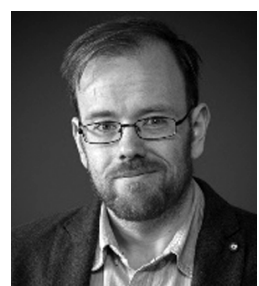

Robert Gillanders (PhD) is Associate Professor of Economics at DCU Business School, Ireland. He is Co-Director of DCU's Anti-Corruption Research Centre (ARC). His main research interests are in development, political economy and public economics, with a particular focus on corruption and governance. He has published many articles on corruption, including recent articles on corruption and access to energy in the journal Energy Policy and anti-corruption policy making in the Journal of Economic Behavior and Organization. 